\title{
PENGARUH HARAPAN, KEPUASAN DAN SARANA FISIK TERHADAP LOYALITAS PELANGGAN \\ (Studi kasus pada Usaha Jasa Warnet di Kudus)
}

\author{
Ratna Yulia Wijayanti \\ Jurusan Syariah dan Ekonomi Islam STAIN Kudus \\ ratnafas@yahoo.com \\ Irsad Andriyanto \\ Jurusan Syariah dan Ekonomi Islam STAIN Kudus \\ irsad.smg@gmail.com
}

\begin{abstract}
This study aimed to examine the effect of variable expectations, satisfaction, and physical facilities on consumer loyalty in the cafe business services both partial and multiple. The independent variables in this study is the expectation, satisfaction, and physical facilities as well as the dependent variable is customer loyalty. Samples taken as many as 83 people with the sampling technique used was accidental sampling, data collection through interviews and questionnaire as well as documentation. As for processing the data using coding, editing and tabulatig and analysis using regression with $t$ test and F-test using SPSS in data processing. By using the above analysis obtained by the research findings that the results of multiple linear regression analysis showed that expectations, satisfaction, and physical facilities partially have a significant influence on customer loyalty. While jointly variable expectations, satisfaction, and physical facilities have a significant effect on customer loyalty by $87.2 \%$, . The implications, limitations and suggestions for future research are also discussed in this article.
\end{abstract}

Keywords: hope, satisfaction, physical facilities, loyalty 


\section{A. Pendahuluan}

Dalam dunia bisnis, persaingan pasti ada, entah itu bersaing dengan sehat ataupun persaingan yang tidak sehat. Banyak pengusaha yang menganggap bahwa pesaing adalah sebagai musuh, tapi sebaenarnya pesaingpun bisa menjadi mitra karena dengan adanya pesaing maka produk yang dihasilkan suatu perusahaan menjadi lebih baik. Hal ini disebabkan karena antara perusahaan yang satu dengan yang lain, berlomba-lomba membuat produk yang berkualitas sehingga tidak kalah dengan perusahaan lain yang pada akhirnya akan menarik perhatian konsumen untuk membeli produk tersebut. Menghadapi pesaing bukanlah hal yang mudah, perusahaan harus mengetahui kondisi pesaing baik dalam maupun luarnya agar perusahaan dapat membuat strategi untuk menghadapi pesaing tersebut

Persaingan usaha menjadi salah satu hal yang hingga saat ini menjadi penting yang harus diperhatikan terlebih antara perusahaan yang sejenis. Persaingan yang sehat akan memberikan kontribusi yang positif jika dalam perusahaan berusaha saling berlomba untuk menghasilkan dampak yang positif bagi perusahaan. Persaingan itu akan membuahkan pelayanan yang berkualitas baik yang nantinya akan berimbas pada loyalitas pelanggan setelah pelanggan menggunakan jasa tersebut atau disebut juga dengan aktifitas yang dilakukan setelah purna beli.

Permasalahan yang besar di hadapi oleh para pelaku bisnis warnet karena dalam dewasa ini. Selain karena bersaing dengan jaringan seluler yang notabene hampir semua orang memilikinya (ponsel), juga karena ketatnya persaingan antar para pengusaha warnet yang mendirikan warnet dengan fasilitas yang serba moderen. Dengan adanya persaingan antara perusahaan yang bergerak dalam bidang sejenis, dalam banyak hal sebenarnya akan menimbulkan dampak positif bagi perusahaan-perusahaan tersebut. Dampak positif tersebut antara lain, perusahaan akan berlomba-lomba memberikan pelayanan dengan kualitas yang terbaik kepada konsumen sehingga konsumen dapat merasakan kepuasan setelah menggunakan jasa layanan perusahaan tersebut. Pelayanan yang berkualitas dan bermutu merupakan salah satu kunci keberhasilan untuk memuaskan pelanggan dalam berbagai 
usaha yang bersifat jasa. Dengan banyaknya pesaing saat ini, upaya untuk mempertahankan konsumen yang loyal merupakan suatu pekerjaan yang membutuhkan tenaga ekstra dan pemikiran yang panjang serta butuh strategi yang jitu untuk memenangkan persaingan.

Berdasarkan rumusan masalah di atas, maka pertanyaan dalam penelitian ini adalah apakah ada pengaruh harapan, kepuasan dan sarana fisik terhadap loyalitas pelanggan baik secara parsial ataupun berganda. Adapun tujuan dari penelitian ini adalah untuk menguji pengaruh harapan, kepuasan dan sarana fisik konsumen baik secara secara parsial ataupun berganda terhadap loyalitas pelanggan.

Penelitian ini diharapkan akan bermanfaat bagi usaha usaha jasa sejenis khususnya bagi pemilik usaha jasa untuk mengambil kebijakan-kebijakan dalam memberikan pelayanan di era globalisasi ini dan waktu yang akan datang dan sebagai referensi dalam melakukan penelitian dan analisa tentang pengaruh loyalitas serta lebih memahami hal hal yang berhubungan dengan loyalitas pelanggan. Selain itu juga sebagai sumbangan pemikiran dan bahan pertimbangan perusahaan untuk meningkatkan daya beli konsumen melalui perwujudan variabel-variabel yang mempengaruhinya serta diharapkan penelitian ini dapat memberikan kontribusi pada pengembangan ilmu manajemen dalam dunia bisnis yang dapat ditindaklanjuti oleh para pengusaha..

\section{B. Pembahasan \\ 1. Kajian Pustaka \\ a. Harapan}

Harapan merupakan perkiraan atau keyakinan pelanggan tentang apa yang akan diterimanya. Pengertian ini didasarkan pada pandangan bahwa harapan merupakan standar prediksi yang dilakukan pelanggan dalam melakukan pembelian. Harapan pelanggan merupakan keyakinan pelanggan sebelum mencoba atau membeli suatu produk, yang dijadikan standar atau acuan dalam menilai kinerja produk tersebut. Meskipun demikian, dalam beberapa hal belum tercapai kesepakatan, misalnya : sifat standar harapan yang spesifik, jumlah standar yang digunakan, maupun sumber harapan.

Model konseptual mengenai harapan pelanggan terhadap 
jasa dipengaruhi oleh faktor-faktor sebagai berikut ini (Sri Mulyani, 2003:87) :

1) Enduring Service Intensifiers

Merupakan faktor yang bersifat stabil dan mendorong pelanggan untuk meningkatkan sensifitasnya terhadap jasa. Faktor ini meliputi harapan yang disebabkan oleh orang lain dan filosofi pribadi seseorang megenai jasa.

2) Kebutuhan Perorangan

Kebutuhan yang dirasakan seseorang mendasar bagi kesejahteraannya juga sangat memerlukan

harapannya. Misalnya kebutuhan fisik, sosial, dan psikologi.

3) Transitory Service Intensifiers

Faktor individual yang bersifat sementara (jangka rendah) yang meningkatkan sensitivitas pelanggan terhadap jasa. Faktor itu mencakup :

a) Situasi darurat pada saat pelanggan sangat membutuhkan jasa dan ingin menyediakan jasa dan dapat membantunya

b) Jasa terakhir yang dikonsumsi pelanggan dapat pula menjadi acuannya untuk menentukan baik-buruknya jasa berikutny

4) Perceived Service Alternatives

Merupakan persepsi pelanggan terhadap tingkat atau derajat pelayanan perusahaan lain yang sejenis. Jika pelanggan memiliki beberapa alternatif, maka harapannya terhadap suatu jasa cenderung akan semakin besar.

5) Self Percuived Service Role

Merupakan persepsi pelanggan tentang tingkat atau derajat keterlibatannya dalam mempengaruhi jasa yang diterimanya. Apabila pelanggan terlibat dalam proses penyampaiannya jasa dan jasa yang terjadi ternyata tidak begitu baik, maka pelanggan tidak bisa menimpakan kesalahan sepenuhnya kepada pihak penyedia jasa.

6) Situational Factors

Faktor situasi terdiri atas segala kemungkinan yang bisa mempengaruhi kinerja jasa yang berada diluar kendali penyedia jasa.

7) Explicit Services Promises / Janji pelayanan secara 
eksplisit

Merupakan pernyataan (secara personal atau non personal) oleh organisasi tentang jasanya kepada pelanggan. Janji ini bisa berupa iklan, personal selling, perjanjian atau komunikasi dengan karyawan organisasi tersebut.

8) Implicit Service Promises / janji pelayanan secara implicit

Merupakan petunjuk yang berkaitan dengan jasa, yang memberikan kesimpulan bagi pelanggan tentang jasa yang bagaimana yang seharusnya, dan yang akan diberikan.

9) Word - of - Mouth / Rekomendasi

Merupakan pernyataan yang disampaikan kepada pelanggan, dan ini biasanya cepat diterima oleh pelanggan karena yang menyampaikan adalah mereka yang dapat dipercaya seperti para pakar, teman, keluarga, dan publikasi media massa.

10) Past Experience / Pengalaman

Merupakan pengalaman masa lampau atau diketahui pelanggan dari yang pernah diterimanya di masa lalu dan harapan ini dari waktu ke waktu berkembang seiring dengan semakin banyaknya informasi yang diterima pelanggan serta semakin bertambahnya pengalaman pelanggan.

Harapan pelanggan melatar belakangi mengapa beberapa organisasi pada bisnis yang sama dapat dinilai berbeda oleh para pelanggannya. Umumnya harapan pelanggan merupakan perkiraan atau keyakinan pelanggan tentang apa yang akan diterimanya. Setiap pelanggan pasti memiliki harapan dalam membuat suatu keputusan pembelian, harapan inilah yang memiliki peran besar sebagai standar perbandingan dalam mengevaluasi kualitas produk tersebut maupun kepuasan konsumen. Ketika konsumen mendapatkan suatu produk sesuai dengan harapannya, maka konsumen akan mempertahankan produk yang di dapatkannya sehingga akan tercipta sikap loyal dari konsumen itu sendiri. Maka dapat disimpulkan bila semakin besar harapan pelanggan yang terpenuhi maka semakin tinggi tingkat loyalitas pelanggan (Valerie. A Zeithaml, 2003:89). 


\section{b. Kepuasan}

Pelanggan yang loyal adalah pelanggan yang tidak akan berhenti hanya sampai hanya pada proses konsumsi. Pelanggan tersebut akan melakukan kegiatan yang berhubungan dengan bertahap akan melakukan proses evaluasi terhadap konsumsi yang telah dilakukannya. Kegiatan ini sering disebut dengan evaluasi alternative pasca pembelian atau konsumsi. Hasil dari proses evaluasi pasca konsumsi adalah pelanggan merasa puas (satisfaction) atau tidak puas (dissatisfaction) terhadap konsumsi produk atau jasa yang sudah dilakukannya. Kepuasan akan mendorong konsumen untuk membeli dan melakukan pembelian ulang produk untuk mengkonsumsi produk tersebut. Sebaliknya perasaan tidak puas akan menyebabkan konsumen kecewa dan menghentikan pembelian kembali atau mengkonsumsi produk tersebut.

Kepuasan didefinisikan sebagai perasaan senang atau kecewa seseorang dari membandingkan kinerja produk yang dirasakan dalam hubungan dan harapannya (Kotler, 2001: 21). Kepuasan didefinisikan sebagai evaluasi setelah pembelian hasil dari perbandingan antara harapan sebelum pembelian dengan kinerja sesungguhnya.Kepuasan merupakan fungsi dari kinerja yang dirasakan (perceived performance) dan harapan (expectations) (Kotler, 2001: 21). Jika kinerja produk atau jasa lebih rendah dari harapan, konsumen jika kinerja sampai melebihi harapan, maka konsumen akan merasa sangat puas (delighted).

Dalam mengukur kepuasan pelanggan terdapat empat metode, yaitu (Kotler dalam Tjiptono, 2006:148) :

1) Sistem keluhan dan saran, artinya setiap perusahaan yang berorientasi pada pelanggan perlu memberikan kesempatan seluas-luasnya bagi para pelanggannya untuk menyampaikan saran, pendapat, dan keluhan Mereka.

2) Media yang bisa digunakan meliputi kotak saran yang diletakkan di tempat-tempat strategis, menyediakan kartu komentar, menyediakan saluran telepon.

3) Survei kepuasan pelanggan, artinya kepuasan pelanggan dilakukan dengan menggunakan metode survei, baik melalui pos, telepon, maupun wawancara pribadi. Dengan melalui survei, perusahaan akan memperoleh tanggapan 
dan umpan balik secara langsung dari pelanggan sekaligus juga memberikan tanda positif bahwa perusahaan menaruh perhatian terhadap para pelanggannya. Pengukuran kepuasan pelanggan melalui metode ini dapat dilakukan dengan berbagai cara,di antaranya sebagai berikut.

a) Directly reported satisfaction, yaitu pengukuran dilakukan secara langsung melalui pertanyaan, seperti sangat tidak puas, tidak puas, netral, puas, dan sangat puas.

b) Derived dissatisfacatin, yaitu pertanyaan yang menyangkut besarnya harapan pelanggan terhadap atribut.

c) Problem analysis, artinya pelanggan yang dijadikan responden untuk mengungkapkan dua hal pokok, yaitu masalah masalah yang mereka hadapi berkaitan dengan penawaran dari perusahaan, dan saran-saran untuk melakukan perbaikan.

d) Importance-performance analysis, artinya dalam teknik ini responden dimintai untuk meranking berbagai elemen dari penawaran berdasarkan pentingnya elemen.

e) Ghost shopping, artinya metode ini dilaksanakan dengan cara memperkerjakan beberapa orang (Ghost shopper) untuk berperan atau bersikap sebagai pelanggan/pembeli potensial produk perusahaan dan pesaing. Kemudian Ghost sopper menyampaikan temuan-temuan mengenai kekuatan dan kelemahan produk perusahaan dan pesaing berdasarkan pengalammereka dalam pembelian produk-produk tersebut.

f) Lost customer analysis, artinya perusahaan menghubungi para pelanggannya yang telah berhenti membeli atau yang telah beralih pemasok dan diharapkan diperoleh informasi penyebab terjadinya hal tersebut.

Salah satu cara dalam mengukur sikap pelanggan ialah dengan menggunakan kuesioner. Perusahaan harus mendesain kuesioner kepuasan pelanggan yang secara akurat dapat memperkirakan persepsi pelanggan tentang mutu barang atau jasa. Penggunaan kuesioner kepuasan pelanggan harus benar- 
benar dapat mengukur dengan tepat persepsi dan sikap pelanggan.

Kepuasan adalah salah satu di antara beberapa penyebab terbentuknya loyalitas. Apabila pelanggan puas terhadap barang atau pelayanan yang diterima, maka akan menimbulkan kesetiaan/loyalitas konsumen. Kepuasan yang dirasakan pelanggan dapat meningkatkan intensitas pembelian, dan dengan tingkat kepuasan yang optimal ini akan mendorong terciptanya loyalitas.

Ketidakpuasan pelanggan disebabkan oleh faktor internal dan faktor eksternal (Tjiptono, 2006:159). Faktor internal yang relatif dapat dikendalikan perusahaan, misalnya karyawan yang kasar, jam karet, kesalahan pencatatan transaksi. Sebaliknya, faktor eksternal yang di luar kendali perusahaan, seperti cuaca, gangguan pada infrastruktur umum, aktivitas kriminal, dan masalah pribadi pelanggan. Lebih lanjut dikatakan bahwa dalam hal terjadi ketidakpuasan, ada beberapa kemungkinan yang bisa dilakukan pelanggan, yaitu :

1) Tidak melakukan apa-apa, pelanggan yang tidak puas tidak melakukan komplain, tetapi mereka praktis tidak akan membeli atau menggunakan jasa perusahaan yang bersangkutan lagi;

2) Ada beberapa faktor yang mempengaruhi apakah seorang pelanggan yang tidak puas akan melakukan komplain atau tidak, yaitu :

a) Derajat kepentingan konsumsi yang dilakukan.

b) Tingkat ketidakpuasan pelanggan,

c) Manfaat yang diperoleh,

d) Pengetahuan dan pengalaman,

e) Sikap pelanggan terhadap keluhan,

f) Tingkat kesulitan dalam mendapatkan ganti rugi,

g) Peluang keberhasilan dalam melakukan komplain.

c. Sarana Fisik

Sarana fisik didefinisikan oleh Parasuraman (2001) yaitu kemampuan suatu perusahaan dalam menunjukkan eksistensinya pada pihak eksternal. Penampilan dan kemampuan sarana dan prasarana fisik perusahaan dan keadaan lingkungan sekitarnya adalah bukti nyata dari pelayanan yang diberikan pemberi jasa. Ini meliputi fasilitas fisik (Gedung, Gudang, dan lainnya), teknologi (peralatan dan 
perlengkapan yang dipergunakan), tersedianya tempat parkir serta penampilan pegawainya. Secara singkat dapat diartikan sebagai penampilan fasilitas fisik, peralatan, personil, dan materi komunikasi.

Sarana fisik meliputi fasilitas fisik, perlengkapan, karyawan, dan sarana prasarana pelayanan. Dalam suatu perusahaan jasa, faktor sarana fisik yang terdiri dari fasilitas fisik, perlengkapan, karyawan, dan sarana prasarana pelayanan, umumnya akan memberikan gambaran bagaimana usaha tersebut dapat berpotensi untuk menunjukkan fungsinya sebagai usaha jasa yang prospektif dan terpercaya.

\section{d. Loyalitas Pelanggan}

Loyalitas/kesetiaan pelanggan mencerminkan niatan berperilaku (intended behavior) berkenaan dengan suatu produk atau jasa. Niatan berperilaku di sini mencakup kemungkinan pembelian mendatang atau pembaharuan kontrak jasa atau sebaliknya, juga seberapa mungkin pelanggan akan beralih ke penyedia layanan atau merek lainnya (Selnes, 2003).

Kesetiaan pelanggan dapat diukur dengan perilaku dan sikap (Getty dan Thompson, 2004:54). Ukuran pertama mengacu perilaku pelanggan pada pengulangan untuk memperoleh atau membeli kembali barang/jasa yang pernah dinikmati. Sedangkan ukuran sikap mengacu pada sebuah intensitas untuk memperoleh kembali dan merekomendasikan kepada orang lain.

Pelanggan yang loyal atau setia adalah orang yang melakukan pembelian ulang dari perusahaan yang sama, serta memberikan informasi yang positif kepada pihak potensial lain dari mulut ke mulut. Agar pelanggan tetap loyal, maka perusahaan harus meyakinkan pelanggannya bahwa perusahaan tersebut mampu memberikan produk atau jasa yang bernilai secara terus menerus. Dalam konteks ini, menguraikan 4 (empat) fase atau tingkatan loyalitas, yaitu (Malai dan Speece, 2002:67):

1) Cognitive loyalty

Loyalitas terbentuk berdasarkan informasi semata. Loyalitas kognitif lebih didasarkan pada karakteristik fungsional, terutama biaya, manfaat dan kualitas. Jika ketiga faktor tersebut tidak baik, pelanggan akan mudah 
pindah ke produk lain. Pelanggan yang hanya mengaktifkan tahap kognitifnya dapat dihipotesiskan sebagai pelanggan yang paling rentan terhadap perpindahan karena adanya rangsangan pemasaran

2) Affective loyalty

Sikap merupakan fungsi dari kognisi pada periode awal pembelian (masa sebelum konsumsi) dan merupakan fungsi dari sikap sebelumnya ditambah dengan kepuasan di periode berikutnya (masa setelah konsumsi). Pada loyalitas afektif, kerentanan pelanggan lebih banyak terfokus pada tiga faktor, yaitu ketidakpuasan dengan merek yang ada, persuasi dari pemasar maupun pelanggan merek lain, dan upaya mencoba produk lain.

3) Conative loyalty

Konasi menunjukkan suatu niat atau komitmen untuk melakukan sesuatu. Niat merupakan fungsi dari niat sebelumnya (pada masa sebelum konsumsi) dan sikap pada masa setelah konsumsi. Maka loyalitas konatif merupakan suatu loyalitas yang mencakup komitmen mendalam untuk melakukan pembelian.

4) Action loyalty

Aspek konatif atau niat untuk melakukan berkembang menjadi perilaku dan tindakan. Niat yang diikuti oleh motivasi, merupakan kondisi yang mengarah pada kesiapan bertindak dan keinginan untuk mengatasi hambatan dalam melakukan tindakan tersebut. Pelanggan yang terintegrasi penuh pada tahap loyalitas tindakan dapat dihipotesiskan sebagai pelanggan yang rendah tingkat kerentanannya untuk berpindah ke produk lain.

Konsumen yang loyal adalah metode yang penting dalam mempertahankan keuntungan dari para pesaing, mengingat memiliki konsumen yang loyal berarti konsumen memiliki keengganan menjadi pelanggan bagi pesaing (Widya Utami, Christina dalam Nugroho dan Paramitha, 2009). Namun demikian, Andreassen dan Lindestad (2008) maupun Selnes (2003) menyatakan bahwa pelanggan mungkin saja menjadi loyal karena hambatan untuk beralih pada produk atau jasa alternatif (switching barriers) yang tinggi berkaitan dengan faktor-faktor teknis, ekonomis, dan psikologis.

Definisi operasional loyalitas pelanggan meliputi 3 (tiga) 
kategori perspektif pengukuran, yaitu :

1) Pengukuran loyalitas berbasiskan perilaku (behavioural measurement).

Dalam perspektif pengukuran ini, pembelian ulang yang konsisten dari pelanggan merupakan indikator utama dari loyalitas pelanggan. Permasalahan terbesar yang dihadapi perspektif pengukuran ini adalah bahwa pembelian ulang belum tentu mencerminkan komitmen pelanggan (secara psikologis) terhadap produk atau jasa yang ditawarkan. Pembelian ulang yang konsisten dapat saja terjadi karena tidak tersedianya atau hanya sedikit tersedia produk atau jasa alternatif yang dirasakan lebih baik;

2) Pengukuran loyalitas berbasiskan sikap (attitudinal measurement).

Dalam perspektif ini, loyalitas diukur dari rasa loyalitas, ikut memiliki, keterlibatan, dan kesetiaan. Contoh nyata dari perspektif ini adalah mungkin seorang pelanggan mempunyai sikap yang sangat bagus terhadap suatu hotel dan merekomendasikan hotel tersebut pada teman dan kerabatnya, namun pelanggan tersebut belum pernah menginap di hotel tersebut dikarenakan tarifnya yang dirasakan terlalu mahal baginya;

3) Perspektif pengukuran ketiga adalah perspektif pengukuran gabungan (composite measurement) di mana perspektif ini merupakan gabungan dari perspektif pertama dan kedua, sehingga loyalitas bisa diukur dari preferensi pelanggan, frekuensi pembelian, kemungkinan untuk beralih pada produk atau jasa alternatif, serta jumlah total pembelian.

Memahami kebutuhan dan keinginan pelanggan, merupakan hal penting yang dapat mempengaruhi loyalitas pelanggan. Pelanggan yang tidak loyal akan menginformasikan 2 (dua) kali lebih hebat kepada orang lain tentang pengalaman buruknya tentang produk atau jasa yang dia terima, sedangkan pelanggan yang loyal akan menginformasikan tentang hal-hal yang terbaik. Oleh karena itu, pelanggan yang loyal merupakan aset yang berharga. Di samping itu, mereka juga merupakan sumber keunggulan bersaing bagi perusahaan. Biaya untuk mendapatkan 
pelanggan baru dan mempertahankan pelanggan yang menguntungkan dijumlahkan, akan merupakan investasi yang besar. Menurut Reichheld dan Sasser (dalam Mittal dan Lassar, 1998), biaya untuk memperoleh seorang pelanggan baru 5 (lima) kali lipat besarnya dari biaya untuk mempertahankan loyalitas seorang pelanggan lama

1) Model Kerangka Pemikiran Teoristis

Variabel Independen Variabel Dependen

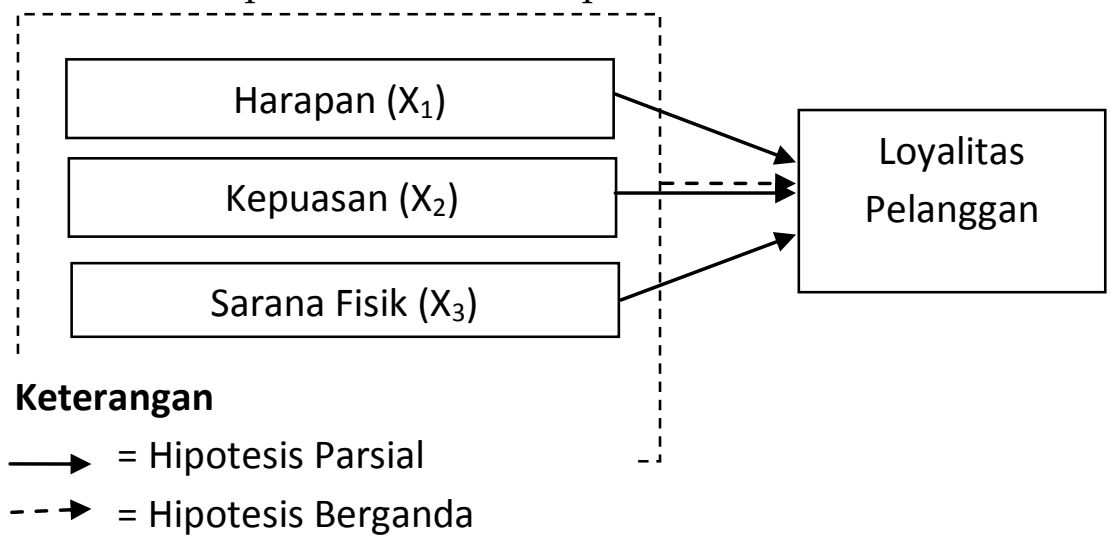

\section{Hipotesis}

Berdasarkan berbagai penelitian diatas, maka penelitian ini menguji empat hipotesis sebagai berikut:

H1 : Harapan yang baik berpengaruh positif terhadap loyalitas kosumen.

$\mathrm{H} 2$ : Kepuasan yang baik berpengaruh positif terhadap loyalitas kosumen.

H3 : Sarana Fisik yang baik berpengaruh positif terhadap loyalitas kosumen.

H4 : Harapan, kepuasan dan sarana fisik yang baik berpengaruh positif terhadap loyalitas kosumen.

\section{Metode}

\section{a. Metode Penelitian}

Tanggapan atas loyalitas tersebut dituangkan dalam kuesioner yang sudah tersedia dengan masing-masing jawaban diberi nilai yang bertingkat, untuk mendapatkan data kuantitatif agar dapat dianalisis dengan menggunakan perhitungan statistik untuk uji angket yaitu validitas dan 
reliabilitas, dan menguji pengaruh serta hubungan dengan regresi dan korelasi berganda. Variabel penelitian yang diteliti ini adalah yaitu variabel harapan, kepuasan dan sarana fisik sebagai variabel bebas/ independent dan loyalitas pelanggan sebagai variabel terikat/ dependen.

Sampel dalam penelitian ini adalah pelanggan warnet sebanyak 83 pelanggan yang menggunakan accidental sampling sebagai teknik samplingnya. Penentuan sampel dilakukan dengan telebih dahulu memastikan bahwa responden adalah seorang pelanggan dengan kriterianya adalah konsumen yang melakukan kunjungan lebih dari tiga kali dalam seminggu. Sampel diambil berdasarkan hari berkunjung yang ramai dan sepi dari pengunjung. Pengumpulan datanya dengan menggunakan wawancara dan quesioner, sedangkan pengolahan datanya menggunakan coding, editing dan tabulating, dan analisnya analisisnya menggunakan regresi dengan uji $t$ dan uji $F$. Identitas pelanggan dalam penelitian ini berdasarkan jenis kelamin, usia, dan pekerjaan

\section{b. Analisis Data}

1) Tanggapan respoden menunjukkan bahwa sebagian besar responden memberikan tanggapan yang sangat setuju dan setuju terhadap keempat indikator variabel harapan pelanggan. Kondisi ini memberikan kesan bahwa responden bersikap baik dalam memberikan tanggapan terhadap indikator harapan pelanggan yang meliputi kebutuhan pribadi, janji pelayanan secara eksplisit, janji pelayanan secara implisit, dan pengalaman masa lampau. Rata-rata skor jawaban adalah sebesar 3,93 yang berada pada kategori tinggi.

2) Tanggapan respoden menunjukkan bahwa sebagian besar responden memberikan tanggapan yang sangat setuju dan setuju terhadap keempat indikator variabel kepuasan. Kondisi ini memberikan kesan bahwa responden mendapatkan kepuasan baik. Hal ini ditunjukkan dengan rata-rata skor variabel kepuasan diperoleh sebesar 3,71 yang berada pada kategori tinggi

3) Tanggapan respoden menunjukkan bahwa sebagian besar responden memberikan tanggapan yang sangat 
setuju dan setuju terhadap keempat indikator variabel sarana fisik. Kondisi ini memberikan kesan bahwa responden mendapatkan sarana fisik yang baik sehingga rata-rata skor variabel sarana fisik diperoleh sebesar 3,97 yang berada pada kategori tinggi.

\section{Model Persamaan Regresi}

Analisis regresi berganda dalam penelitian ini bertujuan untuk mengetahui besarnya pengaruh variabel independen (harapan, kepuasan, dan sarana fisik ) terhadap variabel dependen yaitu loyalitas pelanggan. Ringkasan hasil pengolahan data dengan menggunakan program SPSS tersebut adalah sebagai berikut :

Hasil Analisis Regresi

\begin{tabular}{|c|c|c|c|c|c|c|c|}
\hline \multicolumn{8}{|c|}{ Coefficientsa } \\
\hline \multirow[t]{2}{*}{ Model } & $\begin{array}{l}\text { Unstandardized } \\
\text { Coefficients }\end{array}$ & \multicolumn{2}{|c|}{$\begin{array}{l}\text { Standardized } \\
\text { Coefficients }\end{array}$} & $\mathrm{t}$ & Sig. & & \\
\hline & $\mathrm{B}$ & \multicolumn{2}{|c|}{ Std. Error } & Beta & & & \\
\hline \multirow[t]{4}{*}{1} & (Constant) & \multicolumn{2}{|c|}{2.803} & .573 & & 4.889 & .000 \\
\hline & Harapan (X1) & \multicolumn{2}{|c|}{.347} & .072 & .387 & 4.802 & .000 \\
\hline & Kepuasan (X2) & \multicolumn{2}{|l|}{.168} & .051 & .218 & 3.263 & .002 \\
\hline & Sarana Fisik (X3) & \multicolumn{2}{|c|}{.327} & .067 & .394 & 4.914 & .000 \\
\hline \multicolumn{8}{|c|}{ a. Dependent Variable: Loyalitas Pelanggan $(\mathrm{Y})$} \\
\hline \multicolumn{8}{|c|}{ Coefficients $^{a}$} \\
\hline \multirow{2}{*}{\multicolumn{2}{|c|}{ Model }} & \multicolumn{2}{|c|}{$\begin{array}{l}\text { Unstandardized } \\
\text { Coefficients }\end{array}$} & $\begin{array}{l}\text { Standardized } \\
\text { Coefficients }\end{array}$ & & \multirow{2}{*}{\multicolumn{2}{|c|}{ Sig. }} \\
\hline & & B & \begin{tabular}{|l|} 
Std. \\
Error
\end{tabular} & Beta & $\mathrm{t}$ & & \\
\hline \multirow[t]{4}{*}{1} & (Constant) & 2.803 & .573 & & 4.889 & .000 & \\
\hline & Harapan (X1) & .347 & .072 & .387 & 4.802 & .000 & \\
\hline & Kepuasan (X2) & .168 & .051 & .218 & 3.263 & .002 & \\
\hline & \begin{tabular}{|ll}
$\begin{array}{l}\text { Sarana } \\
\text { (X3) }\end{array}$ & Fisik \\
\end{tabular} & .327 & .067 & .394 & 4.914 & .000 & \\
\hline
\end{tabular}

Dengan penetapan model persamaan yang telah dikemukakan diatas dan telah diolah dengan menggunakan bantuan komputer (program SPPS) model persamaan 
pengaruh variabel $X$ pada signifikan $\alpha=0.05$ untuk lebih jelasnya dapat dilihat pada persamaan sebagai berikut ini.

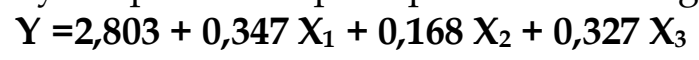

$(4,802) \quad(3,263) \quad(4,914)$

$$
\begin{aligned}
\mathrm{b}_{1}= & 0,347 \text { adalah slope antara } \mathrm{X}_{1} \text { dan } \mathrm{Y} \text {, artinya bahwa } \\
& \text { semakin tinggi variabel harapan yang diberikan, } \\
& \text { maka tingkat loyalitas pelanggan akan naik } \\
& \text { sebesar 0,347, sedangkan variabel yang lain } \\
& \text { dianggap konstan. } \\
\mathrm{b}_{2}= & 0,168 \text { adalah slope antara } \mathrm{X}_{2} \text { dan } \mathrm{Y} \text {, artinya bahwa } \\
& \text { semakin sesuai kepuasan yang diberikan, maka } \\
& \text { tingkat loyalitas pelanggan akan naik sebesar } \\
& 0,168 \text {, sedangkan variabel yang lain dianggap } \\
& \text { konstan. } \\
\mathrm{b}_{3}= & 0,327 \text { adalah slope antara } \mathrm{X}_{3} \text { dan } \mathrm{Y} \text {, artinya bahwa } \\
& \text { semakin tinggi variabel sarana fisik yang } \\
& \text { diberikan, maka tingkat loyalitas pelanggan akan } \\
& \text { naik sebesar } 0,327 \text {, sedangkan variabel yang lain } \\
& \text { dianggap konstan. }
\end{aligned}
$$

Berdasarkan persamaan di atas maka dapat terlihat bahwa variabel yang mempunyai pengaruh paling besar adalah variabel harapan pelanggan yaitu sebesar 0,347. Berarti semakin tinggi harapan pelanggan melalui kebutuhan pribadi, janji pelayanan secara eksplisit, janji pelayanan secara implisit, dan pengalaman masa lampau maka loyalitas pelanggan diwarnet akan semakin meningkat .

\section{Uji t test (parsial)}

Uji t pada dasarnya menunjukkan seberapa jauh pengaruh satu variabel independen secara individual dalam menerangkan variasi variabel dependen dengan asumsi variabel lain konstan. Hasil analisis parsial dengan signifikansi $\alpha=5 \%$ uji satu sisi dapat diketahui sebagai berikut :

\begin{tabular}{|l|l|l|l|l|l|}
\hline \multirow{2}{*}{ Variabel } & \multicolumn{2}{|l|}{$\mathbf{t}_{\text {hitung }}: \mathbf{t}_{\text {tabel }}$} & \multicolumn{2}{l|}{ Prob. Sig } & \multirow{2}{*}{ Keterangan } \\
\cline { 2 - 5 } & $\mathbf{t}_{\text {hitung }}$ & $\mathbf{t}_{\text {tabel }}$ & Sig. & $\alpha=5 \%$ & Signifikan \\
\hline Harapan $\left(\mathrm{X}_{1}\right)$ & 4,802 & 1,664 & 0 & 0,05 & \\
\hline
\end{tabular}




\begin{tabular}{|l|l|l|l|l|l|}
$\begin{array}{l}\text { Kepuasan } \\
\left(X_{2}\right)\end{array}$ & 3,263 & 1,664 & 0,002 & 0,05 & Signifikan \\
\hline $\begin{array}{l}\text { Sarana Fisik } \\
\left(X_{3}\right)\end{array}$ & 4,914 & 1,664 & 0 & 0,05 & Signifikan \\
\hline
\end{tabular}

Sumber $:$ output SPSS df $=\mathrm{n}-\mathrm{k}-1=83-3-1=79, \alpha=5 \% \mathrm{t}$ tabel $=$ 1,664

Adapun hasil analisisnya adalah sebagai berikut :

a. Variabel Harapan pelanggan

Hasil pengujian dengan SPSS diperoleh untuk variabel $\mathrm{X}_{1}$ (harapan pelanggan) diperoleh nilai $\mathrm{t}$ hitung $=4,802>\mathrm{t}$ tabel $=1,664$ dengan tingkat signifikansi 0,000. Dengan menggunakan batas signifikansi 0,05, nilai signifikansi tersebut lebih kecil dari 0,05. Dengan demikian berarti Ha diterima dan Ho ditolak. Dengan demikian maka dapat Hipotesis pertama diterima. Arah koefisien regresi positif berarti bahwa harapan pelanggan yang semakin besar memiliki pengaruh positif yang signifikan terhadap loyalitas pelanggan. Dengan kata lain peningkatan terhadap harapan pelanggan akan meningkatkan loyalitas pelanggan terhadap pelanggan tersebut.

b. Variabel Kepuasan

Hasil pengujian dengan SPSS diperoleh untuk variabel $X_{2}$ (kepuasan) diperoleh nilai t hitung $=3,263$ $>\mathrm{t}$ tabel $=1,664$ dengan tingkat signifikansi 0,002 . Dengan menggunakan batas signifikansi 0,05 , nilai signifikansi tersebut lebih kecil dari 0,05. Dengan demikian berarti Ha diterima dan Ho ditolak. Dengan demikian maka dapat Hipotesis kedua diterima. Arah koefisien regresi positif berarti bahwa kepuasan memiliki pengaruh positif yang signifikan terhadap loyalitas pelanggan. Dengan kata lain peningkatan persepsi terhadap kepuasan akan meningkatkan loyalitas pelanggan.

c. Variabel Sarana Fisik

Hasil pengujian dengan SPSS diperoleh untuk variabel X3 (lokasi) diperoleh nilai $\mathrm{t}$ hitung $=4,914>\mathrm{t}$ tabel $=1,664$ dengan tingkat signifikansi 0,000. Dengan menggunakan batas signifikansi 0,05 , nilai signifikansi 
tersebut lebih kecil dari 0,05. Dengan demikian berarti Ha diterima dan Ho ditolak. Dengan demikian maka dapat Hipotesis ketiga diterima. Arah koefisien regresi positif berarti bahwa sarana fisik memiliki pengaruh positif yang signifikan terhadap loyalitas pelanggan. Dengan kata lain peningkatan sarana fisik yang dilakukan akan meningkatkan loyalitas pelanggan.

\section{Uji F test (berganda)}

Pada dasarnya uji ini digunakan untuk menunjukkan apakah semua variabel harapan pelanggan, kepuasan, dan sarana fisik, mempunyai pengaruh secara bersama-sama terhadap variabel loyalitas pelanggan internet di warnet. Uji F yang digunakan untuk untuk variabel harapan pelanggan, kepuasan, dan sarana fisik, terhadap variabel loyalitas pelanggan menghasilkan nilai $\mathrm{F}_{\text {hitung }}$ sebesar 187,848 dan $\mathrm{F}_{\text {tabel }}$ sebesar 2,720 (diperoleh dari $\mathrm{df}=\mathrm{k}$; $(\mathrm{n}-\mathrm{k})-1=3 ; 79$ ), dengan tingkat signifikan sebesar 0,000. Karena nilai $F_{\text {hitung }}>F_{\text {tabel }}$ dan signifikan tersebut kurang dari 0,05 maka dapat disimpulkan bahwa $\mathrm{H}_{\mathrm{a}}$ yang menyatakan ada pengaruh antara harapan pelanggan, kepuasan, dan sarana fisik terhadap loyalitas pelanggan secara bersama-sama diterima dan Ho yang menyatakan tidak ada pengaruh antara harapan pelanggan, kepuasan, dan sarana fisik, terhadap konsumen dalam loyalitas pelanggan secara bersama-sama ditolak. Berarti variabel harapan pelanggan, kepuasan, dan sarana fisik secara simultan atau bersama-sama dapat mempengaruhi loyalitas pelanggan, artinya hipotesis yang diajukan terbukti. Secara keseluruhan pengusaha sangat memperhatikan harapan pelanggan, kepuasan, dan sarana fisik. Ketiga faktor tersebut yang mampu memberikan dorongan seseorang untuk memutuskan menggunakan jasa warnet tersebut.

\section{Koefesien Determinasi (Adjusted R Square)}

Koefesien Determinasi (Adjusted $\mathrm{R}^{2}$ ) digunakan untuk mengetahui persentase perubahan variabel dependen $(Y)$ yang disebabkan oleh variabel independen (X). Pada uji ini menghasilkan nilai Adjusted $R$ Square sebesar 0,872 atau sebesar $87,2 \%$. Hal ini mengandung arti bahwa pengaruh yang diberikan oleh variabel harapan pelanggan, kepuasan, dan 
sarana fisik secara bersama-sama kepada variabel loyalitas pelanggan adalah sebesar $87,2 \%$.

Dari bentuk persamaan regresi sebagai berikut :

$$
Y=2,803+0,347 X_{1}+0,168 X_{2}+0,327 X_{3}
$$

Diperoleh hasil analisis dengan regresi linier berganda yang menunjukkan adanya pengaruh positif dan signifikan dari harapan pelanggan, kepuasan, dan sarana fisik terhadap loyalitas pelanggan. Hal ini berarti bahwa peningkatan kondisi terhadap ketiga variabel tersebut akan memberikan peluang terhadap meningkatnya loyalitas pelanggan di warnet tersebut. Untuk menguji keberartian model regresi untuk masing-masing variabel secara bersama-sama maupun secara parsial masing-masing variabel dijelaskan sebagai berikut ini.

\section{1) Pengaruh harapan pelanggan terhadap loyalitas pelanggan}

Pengujian hipotesis 1 dari hasil analisis regresi linier berganda diperoleh bahwa variabel harapan pelanggan memiliki pengaruh positif yang signifikan terhadap loyalitas pelanggan dengan nilai koefisien sebesar 0,347 menunjukkan bahwa peningkatan kepuasan akan meningkatkan loyalitas pelanggan. Pelanggan yang merasakan harapannya sesuai dengan yang diberikan, maka ia akan mendapatkan nilai dari jasa yang telah ia beli sebelumnya. Jika kinerja berada dibawah harapan maka akan menimbulkan ketidakpuasan dan apabila kinerja memenuhi harapan, akan menimbulkan suatu kepuasan dan kalau melebihi harapan, konsumen amat puas dan senang. Karena kepuasan ditentukan oleh kualitas layanan sehingga jaminan pelayanan menjadi prioritas utama. Pada banyak model evaluasi jasa, fokus utama terletak pada penilaian komparatif terhadap harapan dan kinerja yang diterima yang menghasilkan dua penilaian evaluatif besar kualitas jasa dan kepuasan. Dengan demikian perusahaan yang mampu memberikan kepuasan kepada konsumen dalam hal ini akan banyak memberikan pengalaman positif bagi konsumen. Konsumen dari pengalaman positif sebelumnya akan 
menentukan seberapa besar pelanggan akan tetap menggunakan produk tersebut sebagai ungkapan loyalitas pelanggan.

2) Pengaruh kepuasan terhadap loyalitas pelanggan

Hasil penelitian analisis regresi linier berganda diperoleh bahwa variabel kepuasan memiliki pengaruh positif yang signifikan terhadap loyalitas pelanggan dengan nilai koefisien sebesar 0,168 menunjukkan bahwa variabel kepuasan secara parsial memiliki pengaruh positif yang signifikan terhadap loyalitas pelanggan. Hasil ini menunjukkan bahwa jika kepuasan produk yang ditawarkan sudah memiliki peranan dalam membantu konsumen dalam mendapatkan manfaat atau kegunaan tertinggi yang diharapkan dari produk tersebut, maka konsumen akan cenderung mempergunakan atau memanfaatkan produk tersebut pada periode berikutnya atau akan melakukan kegiatan pembelian berulang.

3) Pengaruh sarana fisik terhadap loyalitas pelanggan

Pengujian hipotesis terakhir adalah dari hasil analisis regresi linier berganda diperoleh bahwa variabel lokasi memiliki pengaruh positif yang signifikan terhadap loyalitas pelanggan dengan nilai koefisien sebesar 0,327 menunjukkan peningkatan sarana fisik yang dilakukan perusahaan akan meningkatkan loyalitas pelanggan.

Dengan semakin besarnya upaya pembenahan dan pembangunan sarana fisik yang dilakukan warnet tersebut, maka media dan volume informasi yang dilakukan oleh perusahaan untuk menarik konsumen akan semakin besar. Kondisi demikian dapat memberikan daya tarik yang lebih besar bagi konsumen untuk membeli produk yang tersebut. Dengan pengalaman dan ketertarikan terhadap produk tersebut maka konsumen akan semakin loyal dalam menggunakan produk tersebut.

\section{Simpulan}

Dari hasil penelitian adalah terdapat beberapa kesimpulan yaitu : 
1. Ada pengaruh yang signifikan antara variabel harapan pelanggan, kepuasan, dan sarana fisik, terhadap loyalitas pelanggan di warnet secara parsial yang didasarkan pada hasil pengujian diperoleh variabel harapan pelanggan nilai $t_{\text {hitung }}$ sebesar 4,802 , kepuasan nilai $t_{\text {hitung }}$ sebesar 3,263 , dan sarana fisik nilai thitung sebesar 4,914 dari ketiga variabel tersebut memiliki nilai $t_{\text {hitung }}>$ dari nilai $t_{\text {tabel }}$ sebesar 1,662, dan tingkat signifikan di bawah 0,05, namun demikian masih terdapat keluhan dari konsumen terutama terkait dengan harapan pelanggan.

2. Secara berganda ketiga variabel independen yaitu: harapan pelanggan, kepuasan, sarana fisik, berpengaruh signifikan terhadap loyalitas pelanggan yang didasarkan pada nilai $F_{\text {hitung }}$ sebesar 187,848 $>F_{\text {tabel }}$ sebesar 2,720 dan memiliki nilai signifikan di bawah 0,05 , sedangkan kontribusi ketiga variabel tersebut terhadap loyalitas pelanggan memberikan kontribusi sebesar 87,2\%, namun secara keseluruhan penilaian konsumen terhadap harapan pelanggan, kepuasan, dan sarana fisik dirasakan sudah baik.

\section{Saran - Saran}

Berdasarkan hasil dan kesimpulan dalam penelitian ini, berikut adalah beberapa saran sebagai bahan pertimbangan bagi perusahaan:

1. Warnet harus selalu menjaga dan bila perlu meningkatkan kualitas layanan yang menjadi harapan pelangan yang berpengaruh kuat terhadap loyalitas pelanggan, antara lain dengan lebih meningkatkan bandwit, sehingga akses internet lebih cepat.

2. Untuk mewujudkan harapan pelanggan dapat dilakukan oleh warnet dengan mewujudkan harapan-harapan pelanggan dengan tujuan mempertahankan loyalitas pelanggan dengan pelayanan yang semakin baik.

3. Untuk mewujudkan kepuasan pelanggan dalam memenuhi kebutuhan dan keinginan pelanggannya pemilik warnet harus berusaha meraih pangsa pasar 
Pengaruh Harapan, Kepuasan dan Sarana Fisik ...

yang lebih besar dengan menyediakan ruang tunggu yang nyaman dan aman serta representatif sehingga dapat menciptakan konsumen yang makin loyal pada produk jasa warnet.

4. Variabel harapan pelanggan, kepuasan pelanggan dan sarana fisik secara bersama sama berpengaruh sebesar $87,2 \%$ terhadap variabel loyalitas pelanggan, sehingga sisanya sebesar $12,8 \%$ dapat dijelaskan oleh variabel yang lain yang akan dilakukan oleh peneliti lain untuk semakin menambah khasanah dan wawasan bagi para pengusaha jasa khususnya pengusaha warnet ini agar loyalitas konsumen semakin total tercapai. 
Ratna Yulia Wijayanti dan Irsad Andiyanto

\section{Daftar Pustaka}

Algifari. 2000. Analisis Regresi Teori. Kasus dan Solusi Edisi 2. BPFE: Yogyakarta.

Budi, Purbayu, Santoso, dan Ashari. 2005. Analisis Statistik dengan Microsoft Excel dan SPSS. ANDI, Jogjakarta.

Basar, Adhy dan Ismady Ihsan. 2009. Kondisi Perbankan 2009 dan Prospek 2010" Economic Review, No. 218, Diakses tanggal 10 Juni 2010 dari berita Ekonomi.

Basu, Swastha, \& Irawan. 2001. Manajemen Pemasaran Modern. Liberty. Yogyakarta.

Chan, Syafruddin. 2003. Relationship Management. Gramedia Pustaka Utama. Jakarta.

Dharmayanti. 2006. Analisis Dampak Servie performance dan kepuasan sebagai Moderating Variabel terhadap Loyalitas. Faculty of Economic, Petra Christian University

Dharmmesta, Basu Swastha. 2009. Loyalitas Pelanggan: Sebuah Kajian Konseptual Sebagai Panduan Bagi Peneliti." Jurnal Ekonomi dan Bisnis Indonesia, Vol.14, No 3

Dinar Ika Pratiwi. 2010. Analisis Pengaruh Harapan Pelanggan, Kualitas Produk, Kepuasan Pelanggan Terhadap Loyalitas Pelanggan Internet Flash Unlimited Di Semarang. UNDIP. Semarang.

Fandy Tjiptono. 2006. Strategi Pemasaran. Edisi Kedua. Cetakan Keenam. Penerbit. Andy. Yogyakarta.

Ferdinand. 2006. Metode Penelitian Manajemen : Pedoman Penelitian untuk Penulisn Skripsi. Tesis, dan Disertasi, BP: Undip: Semarang. 
Pengaruh Harapan, Kepuasan dan Sarana Fisik ...

Frizsimmons, James A, and Mona J. Fritzsimmons. 1994. Service Management for Competitive Advantage, McGrraw- Hill, Inc. New York.

Ghozali, Imam. 2006. Analisis Multivariate Lanjutan dengan Program SPSS, BP. UNDIP, Semarang.

Griffin, Jill 2005. Customer Loyalty : menumbuhkan dan Mempertahankan Kesetiaan Pelanggan, Alih Bahasa : Dwi Kartini Yahya, dkk Erlangga, Jakarta.

Husein, Umar. 2005. Riset Pemasaran \& Perilaku Konsumen, Gramedia Pustaka Utama, Jakarta.

Kandampully \& Suhartanto. 2000. D, Customer Loyalty in the Hotel Industry : the Role of Customer Satisfaction and Image International Journal of Contemporary Hostpitality Management, 12

Kotler, Philip. 2001. Marketing. Erlangga. Jakarta.

Lupiyoadi, Rambat. 2001. Manajemen Pemasaran Jasa. Edisi 1. Salemba Empat. Jakarta.

Peter, Paul dan Jerry. C. Olson. 2000. Consumer Behaviour. Edisi 4 (terjemahan). Erlangga. Jakarta.

Rangkuti, Freddy. 2006. Mersuring Customer Satisfaction, Gramedia, Jakarta.

Rambat Lupiyoadi. 2004. Manajemen Pemasaran Jasa. Salemba Empat. Jakarta.

Sri, Mulyani. 2003. Dampak Kualitas Jasa Pelayanan Terhadap Perilaku Konsumen. Jurnal Gemawisata Vol. II No. 1, 2003.

Suharsimi Arikunto. 2001. Prosedur Penelitian. Rineka Cipta. Yogyakarta Supranto. Metode Penelitian. Erlangga. Jakarta. 
Ratna Yulia Wijayanti dan Irsad Andiyanto

Tjiptono, Fandy and Gregorius Chandra. 2005. Service, Quality, Satisfaction. Penerbit ANDI. Yogyakarta.

Ujang Sumarwan. 2003. Perilaku Konsumen: Teori dan Penerapannya dalam Pemasaran (Consumer Behaviour: Theory and Application in Marketing).

Valerie. A Zeithaml. 2003. Service Marketing. McGraw Hill Companies Inc., New York.

Wijaya, Serly dan Thio, Sienny. 2006. Implementasi Membership Card dan Pengaruhnya dalam Meningkatkan Loyalitas Pengunjung Restoran di Surabaya. Fakultas Ekonomi Universitas Kristen Petra. 